\title{
Analisis Validitas dan Reliabilitas Perangkat Pembelajaran Model Penemuan terbimbing berbasis Home Visit
}

\author{
Budiman \\ STKIP Yapis Dompu, Nusa Tenggara Barat, Indonesia \\ E-mail: budimanmsaid@gmail.com
}

\begin{tabular}{|c|c|}
\hline Article Info & Abstract \\
\hline $\begin{array}{l}\text { Keywords: } \\
\text { Validity; } \\
\text { Learning Media; } \\
\text { Guided Discovery; } \\
\text { Home Visits. }\end{array}$ & $\begin{array}{l}\text { An analysis of the validity and reliability of the guided discovery learning model based } \\
\text { on a home visit has been carried out. The learning tools developed have } 4 \text { components, } \\
\text { including teaching materials, worksheets, lesson plans, and concept mastery test } \\
\text { instruments. These four components were each validated by two experts in the field of } \\
\text { science concepts and the fields of design and language. Based on the results of expert } \\
\text { analysis regarding the validity and reliability of home visit-based guided discovery } \\
\text { learning tools, it can be concluded that all components of learning devices developed } \\
\text { are valid and reliable with the average acquisition of all components of equipment } 3.5 \\
\text { (valid) and reliability of } 98 \% \text {. Thus, the developed device is feasible to be used and } \\
\text { implemented at the device testing stage. }\end{array}$ \\
\hline Artikel Info & Abstrak \\
\hline $\begin{array}{l}\text { Kata kunci: } \\
\text { Validitas; } \\
\text { Perangkat pembelajaran; } \\
\text { Guided Discovery; } \\
\text { Home Visit. }\end{array}$ & $\begin{array}{l}\text { Telah dilakukan analisis validitas dan reliabilitas perangkat pembelajaran model } \\
\text { penemuan terbimbing (guided discovery) berbasis home visit. Perangkat pembelajaran } \\
\text { yang dikembanga ada } 4 \text { komponen antara lain materi ajar, LKS, RPB, dan intrumen tes } \\
\text { penguasaan konsep. Empat komponen ini masing divalidasi oleh dua orang pakar/ahli } \\
\text { dalam bidang konsep IPA dan bidang desain dan bahasa. Berdasarkan hasil analisis } \\
\text { pakar mengenai validitas dan reliabilitas perangkat pembelajaran model penemuan } \\
\text { terbimbing (guided discovery) berbasis home visit dapat disimpulkan bahwa seluruh } \\
\text { komponen perangkat pembelajaran yang dikembangakn valid dan reliabel dengan } \\
\text { perolehan rerata seluruh komponen perangat 3,5 (valid) dan reliabilita 98\%. Dengan } \\
\text { demikian perangkat yang dikembangkan layak untuk digunakan serta } \\
\text { diimplementasikan pada tahap ujicoba perangkat. }\end{array}$ \\
\hline
\end{tabular}

\section{PENDAHULUAN}

Setiap warga negara wajib mengikuti pendidikan dasar dan pemerintah wajib membiayainya" (Pasal 31 Ayat 2 UUD 1945). Undang-undang di atas dimaknai bahwa semua warga negara wajib dan berhak mendapat pendidikan yang layak tanpa mengenal suku, ras, agama dan latar belakang pendidikan. Namun semenjak adanya bencana nasional Pandemik Covid-19 seolah peryantaan di atas terdapat kesenjangan antara harapan dengan kenyataan. Dengan adanya pandemi virus korona, sistem pembelajaran terpaksa berubah. Dari belajar secara tatap muka di sekolahan menjadi belajar dengan media online. Sayangnya, sistem pembelajaran ini tak bisa dinikmati oleh sebagian siswa. Khususnya, siswa yang bertempat tinggal di pelosok. Hingga tidak memiliki fasilitas penunjang untuk mendapatkan materi melalui daring ataupun online.

Sebagai upaya memperlancar proses pembelajaran dimasa pandemic covid 19, Kepala Dinas Pendidikan dan Kebudayaan (Dikbud) NTB H Aidy Furqan mengintruksikan sekolah untuk mengaktifkan home visite. Dalam pernyataannya pada salah satu media online (Lombok Post/3 Mei, 2020) beliau mengungkapkan "Sekitar 1520 persen siswa di NTB tidak bisa belajar di rumah baik itu secara semi online maupun online, lalu beliau berpendapat bahwa home visite merupakan alternatif yang tepat dalam proses pembelajaran pada masa pandemik terutama pada daerah yang tidak bisa melaksanakan pembelajaran daring disebabkan tidak ada fasilitas pendukung". Beliau melanjutkan bahwa "untuk diketahui, home visit merupakan salah satu teknik pengumpul data dengan jalan mengunjungi siswa. Di home visit itu, sekolah bisa menugaskan guru BK atau guru mata pelajaran (bersangkutan) untuk menangani siswa yang tidak bisa mendapatkan materi pembelajaran secara daring. Sejalan dengan Kadis Dikbud NTB, Syfa dkk (2020) dalam jurnalnya yang berjudul "implementasi program Home Visite dalam mengatasi problem belajar siswa sekolah dasar" berpendapat bahwa "kunjungan rumah atau home visite adalah proses berkunjung kerumah siswa untuk 
membantu menyelesaikan problem yang dialami oleh siswa, dalam rangkah mencari dan melengkapi data atau informasi siswa mengenai permasalahan proses pembelajaran".

Pembelajaran dikatakan efektif apabila proses belajar mengajar berjalan dengan baik sesuai dengan tujuan belajar dan hasil belajar (Ibrahim, 2010). Oleh karena itu, untuk menyelaraskan proses pembelajaran yang baik maka dibutuhkan peranan guru yang tepat dalam menjalankan proses pembelajaran seperti pemilihan metode, media dan bagaiman mengevaluasi peserta didik. Salah satu model pembelajaran yang dirasa dapat diterapkan guru sebagai pendekatan pembelajaran aktif yaitu model guided discovey (penemuan terbimbing).

Guided discovery merupakan model yang sangat efektif karena memuat dua kriteria penting dalam pembelajaran aktif, yaitu membangun pengetahuan yang tepat untuk mempermudah pemahaman tentang informasi baru dan menyempurnakan informasi tersebut atas dasar yang dimiliki siswa atas dukungan guru, lingkungan atau dorongan yang kuat dalam dirinya sendiri (Abdisa, 2012). Menguasai konsep yang baik, siswa memiliki kemampuan keterampilan yang baik pula. Keberhasilan siswa dalam memahami materi pelajaran, tergantung pada guru sebagai pembimbing yang harus bertindak sebagai motivator dan fasilitator yang baik (Munandar, 2009).

Salah satu komponen penting dalam menentukan kualitas pembelajaran harus didukung dengan adanya perangkat pembelajaran yang memadai sesuai kebutuhan peseta didik. Perangkat pembelajaran yang memadai tentunya diukur dengan seberapa besar kualitas kelayakan dari perangkat pembelajaran yang ada (Adha, 2013). Indikator kelayakan suatu perangkat salah satunya bisa dilihat dari validitas dan reliabilitas perangkat yang dibuat. Validitas diartikan sebagai keabsahan suatu perangkat yang telah diakui oleh pakar/ahli sehingga memiliki hasil/ nilai yang dapat mengukur apa yang diukur, sedangkan reliabilitas merujuk pada konsistensi skor yang dicapai oleh orang/produk/perangkat yang sama ketika diuji ulang dengan instrument yang sama. Arti sederhanya adalah relibilitas merupakan konsistensi nilai.

Perangkat pembelajaran terdiri dari beberapa komponen diantaranya, materi ajar, lembar kerja siswa, rencana pelaksanaan pembelajaran, instrument tes hasil belajar, dan lain-lain (Depdiknas, 2010). Diantara yang disebut di atas tentunya tidak bisa diaplikasikan sebelum dilakukan tahap pengujian valditas dan pengujian reliabilitas dari pada perangkat tersebut. Untuk itu dalam pelaksanaan pembelajaran seyogyanya perangkat pembelajaran harus terlebih dulu divalidasi agar kualitas pembejaran tercapai sesuai ekspetasi.

Atas dasar latar belakang di atas maka peneliti mencoba menganalisis validitas dan reliabilitas perangkat pembelajaran model penemuan terbimbing (guided discovery) berbasis home visit, dengan tujuan mengetahui tingkat kelayakan dari perangkat yang dikembangkan. Perangkat pembelajaran ini juga diharapankan dapat membantu meningkatkan efektivitas proses pembelajaran khusus di sekolah dasar yang tidak bisa didukung dengan pembelajaran daring.

\section{METODE PENELITIAN}

Jenis penelitian ini adalah penelitian pengembangan, penelitian pengembangan ini dilaksanakan untuk menghasilkan perangkat pembelajaran model penemuan terbimbing (guided discovery) berbasis home visit yang valid sehingga dapat digunakan untuk implementasi atau ujicoba pada proses pembelajaran berbasis home visit (pembelajaran di rumah). Perangkat pembelajaran ini dirancang untuk pembelajaran siswa sekolah dasar kelas $\mathrm{V}$ dengan tema ekosistem. Perangkat yang dikembangkan peneliti antara lain, bahan ajar siswa, lembar Kerja siswa (LKS), RPB (rencanan pelaksanaan bimbingan) dan instrument tes pegguasaan konsep siswa.

Prosedur penelitian dalam pengembangan perangkat pembelajaran ini menggunakan modifikasi model yang dikembangkan oleh Dick dan Carey dalam tulisannya The Systematic Design of Instruction (dalam Lavine, 2005). Dick dan Carey mengembangkan model desain pembelajaran tersebut berdasarkan pemikiran Gagne, The Conditions of Learning (Lavine, 2005). Edisi pertama tulisan Dick dan Carey menggunakan pendekatan sistem dan perilaku, namun pada edisi selanjutnya mereka menambahkan unsur dan pandangan kognitif dalam proses belajar dan pembelajaran. Jadi, model yang dikembangkan oleh Dick dan Carey didasarkan pada pendekatan sistemik, artinya dimulai dari analisis, desain, pengembangan, implementasi, dan evaluasi. Selain sistematis dan lengkap, alasan pemilihan model Dick dan Carey dalam pengembangan perangkat 
pembelajaran ini adalah karena tahapannya dapat dilaksanakan peneliti.

Perangkat pembelajaran seluruhnya dikembangkan mengacu pada model Dick dan Carey, selanjunya divalidasi oleh dua orang pakar ahli dengan menggunakan instrument validasi berupa lembar validasi. Terdapat dua validasi yang digunakan dalam penelitian ini yaitu validasi isi (content validity) dan validasi konstruk (construct validity) (Riduwan, 2010). Skala Pengukuran variabel-variabel penelitian. Bandung: Alfabeta.. Dua jenis validasi ini tertuang dalam satu lembar validasi. Kriteria validitas perangkat yang dikembangakn menggunakan mengacu pada tabel berikut:

Tabel 1. Kriteria Validitas Perangkat

(Ratumanan \& Laurens, 2011)

\begin{tabular}{ccl}
$\begin{array}{c}\text { Interval } \\
\text { Skor }\end{array}$ & $\begin{array}{c}\text { Kategori } \\
\text { Penilaian }\end{array}$ & Kategori Penilaian \\
\hline $3.6 \leq \mathrm{P} \leq 4$ & Sangat valid & $\begin{array}{l}\text { Dapat digunakan } \\
\text { tanpa revisi }\end{array}$ \\
\hline $2.6 \leq \mathrm{P} \leq 3.5$ & valid & $\begin{array}{l}\text { Dapat digunakan } \\
\text { dengan sedikit revisi }\end{array}$ \\
\hline $1.6 \leq \mathrm{P} \leq 2.5$ & Kurang valid & $\begin{array}{l}\text { Dapat digunakan } \\
\text { dengan revisi banyak }\end{array}$ \\
\hline $1 \leq \mathrm{P} \leq 1.5$ & Tidak valid & $\begin{array}{l}\text { Belum bisa } \\
\text { digunakan dan masih } \\
\text { revisi }\end{array}$ \\
\hline
\end{tabular}

Perangkat pembelajaran yang telah dikembangkan kemudian dihitung persentase reliabilitasnya. Perhitungan reliabilitas perangkat pembelajaran menggunakan rumus (Borich, 2007) sebagai berikut.

$R=\left[1-\frac{A-B}{A+B}\right] \times 100 \%$

\section{Keterangan:}

R : Reliabilitas

A : Frekuensi aspek tingkah laku yang teramati oleh pengamat yang memberikan frekuensi tinggi.

B : : Frekuensi aspek tingkah laku yang teramati oleh pengamat yang memberikan frekuensi rendah.

Instrumen yang dikembangkan dikatakan reliabel jika mempunyai persentase $\geq 70 \%$.

\section{HASIL DAN PEMBAHASAN}

\section{Analisis Hasil Validasi dan Reliabilitas Perangkat Pembelajaran}

Perangkat pembelajaran yang dikembanga ada 4 kmponen antara lain materi ajar, LKS, RPB, dan intrumen tes penguasaan konsep. Empat komponen ini masing divalidasi oleh dua orang pakar/ahli dalam bidang konsep IPA dan bidang desain dan bahasa. Hasil masing-masing validasi perangkat digambarkan sebagai berikut:

Tabel 2. Hasil Validasi dan Reliabilitas Materi Ajar

\begin{tabular}{|c|c|c|c|c|}
\hline $\begin{array}{c}\text { Aspek yang } \\
\text { dinilai }\end{array}$ & V1 & V2 & Rerata & Kategori \\
\hline Isi & 3,3 & 3,6 & 3,4 & $\mathrm{~V}$ \\
\hline Bahasa & 3,3 & 3,8 & 3,5 & $\mathrm{~V}$ \\
\hline Format & 3,6 & 3,3 & 3,5 & $\mathrm{~V}$ \\
\hline Rerata & 3,4 & 3,5 & 3,5 & $\boldsymbol{V}$ \\
\hline \multicolumn{5}{|c|}{ Keterangan: $\mathrm{V} 1 / 2=$ validator $1 / 2 ; \mathrm{V}=$ valid } \\
\hline \multirow{2}{*}{ Reliabilitas } & V1 & V2 & $\begin{array}{c}\text { Rerata } \\
(\%)\end{array}$ & \multirow{2}{*}{ Reliabel } \\
\hline & 3,4 & 3,5 & 97 & \\
\hline
\end{tabular}

Komponen validasi materi ajar siswa oleh dua validator berupa format, isi, dan bahasa. Tabel 2 menunjukkan rata-rata hasil validasi materi ajar siswa oleh dua validator adalah 3,4 sampai 3,5 dengan kategori valid dengan rata-rata reliabilitas $97 \%$.

Tabel 3. Hasil Validasi dan Reliabilitas Lembar Kerja Siswa (LKS)

\begin{tabular}{ccccc}
\hline $\begin{array}{c}\text { Aspek } \\
\text { yang } \\
\text { dinilai }\end{array}$ & V1 & V2 & Rerata & Kategori \\
\hline Format & 3,5 & 3,8 & 3,6 & SV \\
\hline Isi & 3,8 & 3,8 & 3,8 & SV \\
\hline Bahasa & 3,0 & 3,3 & 3,2 & V \\
\hline Rerata & $\mathbf{3 , 4}$ & $\mathbf{3 , 6}$ & $\mathbf{3 , 5}$ & $\mathbf{V}$ \\
\hline & & & & \\
\hline \multirow{2}{*}{ Reliabilitas } & V1 & V2 & $\begin{array}{c}\text { Rerata } \\
(\mathbf{\%})\end{array}$ & \\
\cline { 2 - 4 } & 3,4 & 3,6 & 98 & Reliabel \\
\hline
\end{tabular}

Komponen validasi LKS oleh dua validator berupa format, isi, dan bahasa. Tabel 3 menunjukkan rata-rata hasil validasi LKS oleh dua validator adalah 3,4 sampai 3,6 dengan kategori valid dan sangat valid dengan rata-rata reliabilitas $98 \%$.

Tabel 4. Hasil Validasi dan Reliabilitas Rencana Pelaksanaan Pembelajaran Berbasis home visit

\begin{tabular}{ccccc}
$\begin{array}{c}\text { Aspek } \\
\text { yang } \\
\text { dinilai }\end{array}$ & V1 & V2 & Rerata & Kategori \\
\hline Format & 3,3 & 3,5 & 3,4 & SV \\
\hline Isi & 3,3 & 3,3 & 3,3 & SV \\
\hline Bahasa & 3,4 & 3,6 & 3,5 & SV \\
\hline
\end{tabular}




\begin{tabular}{|c|c|c|c|c|}
\hline Rerata & 3,4 & 3,5 & 3,4 & \\
\hline \multirow{2}{*}{$\begin{array}{c}\text { Reliabil } \\
\text { itas }\end{array}$} & V1 & V2 & $\begin{array}{c}\text { Reliabel } \\
\%\end{array}$ & \multirow[t]{2}{*}{ Reliabel } \\
\hline & 3,4 & 3,5 & 97 & \\
\hline
\end{tabular}

Komponen validasi RPB oleh dua validator berupa format, isi, dan bahasa. Tabel 4 menunjukkan rata-rata hasil validasi RPB iswa oleh dua validator adalah 3,4 sampai 3,5 dengan kategori valid dengan rata-rata reliabilitas $97 \%$.

Tabel 5. Hasil Validasi dan Reliabilitas Intrumen Tes Penguasaan Konsep

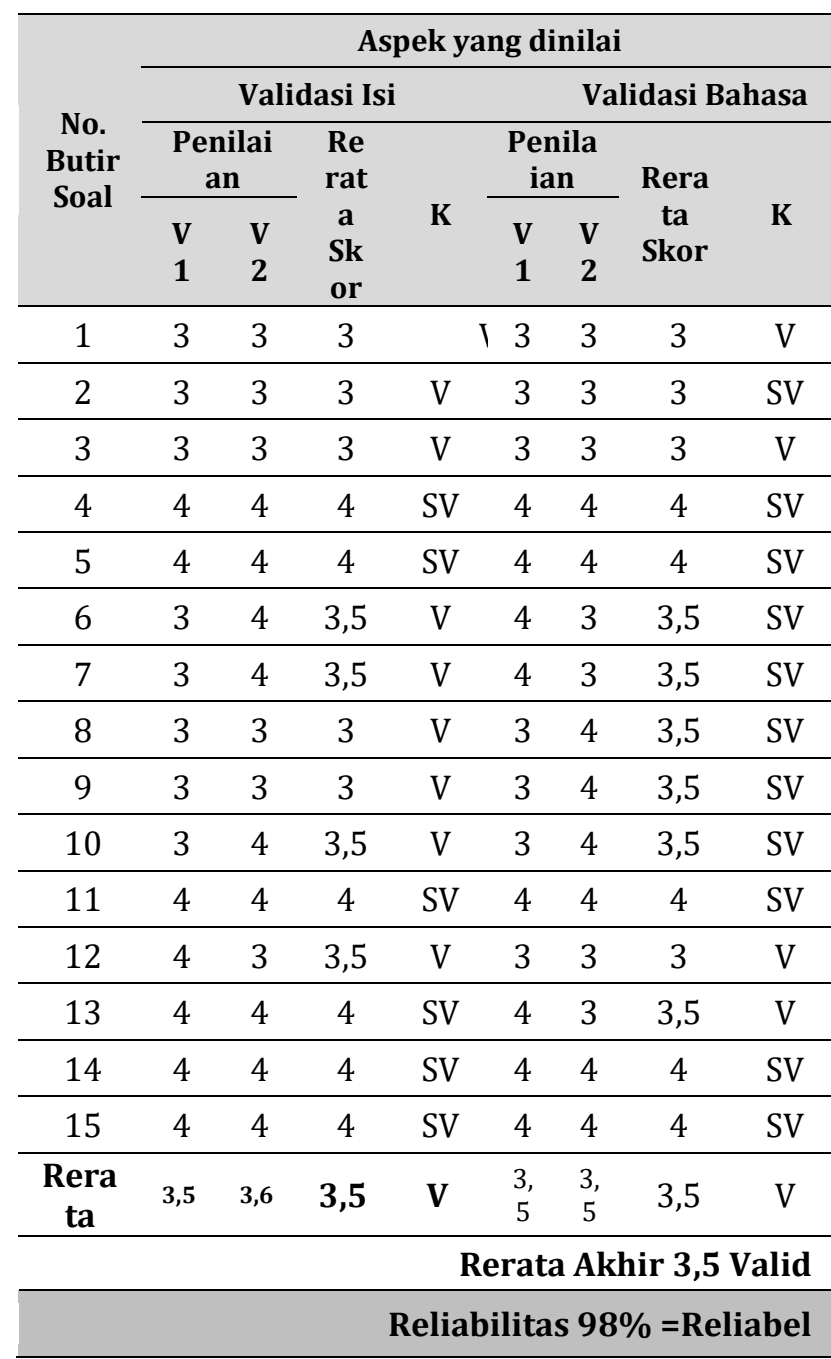

Komponen validasi Intrumen Tes Penguasaan Konsep oleh dua validator berupa format, isi, dan bahasa. Tabel 4 menunjukkan rata-rata hasil validasi Intrumen Tes Penguasaan Konsep oleh dua validator adalah 3,5 dengan kategori valid dengan rata-rata reliabilitas $98 \%$.

\section{SIMPULAN}

Berdasarkan hasil analisis pakar mengenai validitas dan reliabilitas perangkat pembelajaran model penemuan terbimbing (guided discovery) berbasis home visit dapat disimpulkan bahwa seluruh komponen perangkat pembelajaran yang dikembangakn valid dan reliabel dengan perolehan rerata seluruh komponen perangat 3,5 (valid) dan reliabilita 98\%. Dengan demikian perangkat yang dikembangkan layak untuk digunakan serta diimplementasikan pada tahap ujicoba perangkat.

\section{DAFTAR RUJUKAN}

Abdisa, G. dan Getinet T., (2012), The Effect of Guided Discovery on Students'. Physics Achievement, Lat. Am. J. Phys. Educ., 6 (4) 530-537.

Adha, Mona \& Yanzi, Hermi. 2013. Model Pengembangan Pembelajaran. Jakarta: Penerbit Erlangga.

Borich, G.D. (2007). Effective Teaching Methods Research-Based Practice Sixth Edition. New Jersey: Pearson Merrill Prentice Hall.

Depdiknas. 2010. Juknis Pengembangan Bahan Ajar SMA. Jakarta: Direktorat Pembinaan Sekolah Dasar.

Fathirma'ruf. (2021). Pengembangan Game Edukasi Berbasis Flash Sebagai Sarana Belajar Siswa PAUD. Ainara Journal (Jurnal Penelitian Dan PKM Bidang Ilmu Pendidikan), 2(3), 143-147. Retrieved from

http://journal.ainarapress.org/index.php/ ainj/article/view/68

Ibrahim, M. (2010). Dasar-dasar proses belajar mengajar. Surabaya: Unesa University Press.

Ilham. (2021). Kebijakan Kepala Sekolah untuk Meningkatkan Mutu Pendidikan Sekolah Dasar. Ainara Journal (Jurnal Penelitian Dan PKM Bidang Ilmu Pendidikan), 2(3), 154-161. Retrieved from http://journal.ainarapress.org/index.php/ ainj/article/view/70

Lavine, R.A. (2005). Guided Discovery learning with videotaped case presentation in neurobiology. Department of Pharmacology \& Physiology The George Washington University School of Medicine and Health Sciences Washington, DC 20037 U.S.A. Diakses 12 Desember 2013.

Lombok Post. (2020) Diakses pada 10 Oktober 2010 pada laman ttps://lombokpost.jawapos.com/ntb/04/0 
5/2020/home-visit-jadi-alternatifpembelajaranditengah pandemi-viruskorona/.

Munandar,Utami.(2009). Pengembangan kreativitas anak berbakat. Jakarta:Rineka cipta.

Peraturan Menteri Pendidikan dan Kebudayaan RI Nomor 67 Tahun 2013 Tentang Kerangka Dasar dan Struktur Kurikulum Sekolah Dasar/Madrasah Ibtidaiyah.
Ratumanan. T.G, Laurens. T. 2011. Penilaian Hasil Belajar Pada Tingkat Satuan Pendidikan. Edisi 2. Unesa University Press.

Riduwan, (2010). Skala Pengukuran variabelvariabel penelitian. Bandung: Alfabeta.

Taufik, \& Andang. (2021). Efektivitas Pembelajaran Membaca Puisi dengan Teknik Skema pada Siswa SMP Kelas VIII. Ainara Journal (Jurnal Penelitian Dan PKM Bidang Ilmu Pendidikan), 2(3), 162168. Retrieved from http://journal.ainarapress.org/index.php/ ainj/article/view/72 